See discussions, stats, and author profiles for this publication at: https://www.researchgate.net/publication/220798157

\title{
Preliminary investigation of project success criteria in Norway
}

Conference Paper · September 2011

DOI: 10.1109/IDAACS.2011.6072906 · Source: DBLP

\section{CITATION}

1

3 authors, including:

(7) Bassam Hussein

Norwegian University of Science and Technology

71 PUBLICATIONS 184 CITATIONS

SEE PROFILE
READS

200

(2) Sara Hajikazemi

16 PUBLICATIONS 71 CITATIONS

SEE PROFILE

Some of the authors of this publication are also working on these related projects:

Performance Measurement in Norwegian Construction Industry View project

Using innovative learning methods to overcome the distance barrier in engineering education. View project 


\title{
Preliminary Investigation of Project Success Criteria in Norway
}

\author{
Bassam A. Hussein \\ Saeed Ramazany, Sara Haji-kazemi \\ Norewgian University of Science and Technology, NTNU, Trondheim-Norway \\ bassam.hussein@ntnu.no, ramazany@stud.ntnu.no, hajikazemi@ntnu.no
}

\begin{abstract}
The goal of this investigation is to examine the types of project management criteria used in projects in Norway. The results suggest that investigated projects are managed using an incomplete set of success criteria. Projects are poorly aligned with corporate strategies and users needs. They are poorly initiated and focus only on narrow operational goals. The results also indicate that these criteria undergo several changes during the execution phase, which can cause the project to lose focus and generate unwanted outcomes such as delays, unsatisfied users and financial losses.
\end{abstract}

\section{Keywords—success criteria; project management}

\section{The CONCEPT OF Project SuCcess}

Projects are initiated in order to create change by establishing new products and services or creating new organisations and processes [1]. Therefore, project success means different things for different stakeholders along the entire project and product life cycle. Freeman and Beale [2] noted that success means different things to different people. An architect may consider success in terms of aesthetic appearance, an engineer in terms of technical competence, an accountant in terms of dollars spent under budget and a human resources manager in terms of employee satisfaction. Chief executive officers rate their successes on the stock market.

Muller [3] stated that views on project success have changed over the years from definitions that were limited to the implementation phase of the project life cycle to definitions that reflect an appreciation of success over the entire project and product life cycle. Project success has long been considered the ability to comply with time, cost and quality constraints. These criteria are called in the literature "golden triangle" or project management success because they are concerned with the efficiency of the performing project organisation [4]. However, there are lots of examples of projects that were not delivered within time, cost and scope constraints but that still were perceived as successful projects. for example the Sydney Opera House or the introduction of the Windows operating system [5]. This led De Wit [6] to suggest a distinction between project success and project management success. Similar frameworks were suggested by Baccarini [7], who also distinguished between project management success and project success, and Lim and Mohamed [8], who made the distinction between micro and macro success. The micro perspective refers to success as seen by the contractor or performing organisation and the developer during the implementation phase. The macro perspective refers to success as seen by other stakeholders and users over the entire life cycle.

Shenhar [9] distinguished between 4 distinct success dimensions: (1) project efficiency, (2) benefit to the customer, (3) direct business and organisational success of the performing organisation and (4) preparing for the future. These dimensions represent different points of view, the different concerns of the organisation and different time horizons.

The goal of this paper is not to propose a new conceptual framework for project success or to provide a full literature review about the notion of success. Our aim is to investigate and provide an overview of the categories and types of success criteria in Norway.

\section{RESEARCH METHOD}

A questionnaire was developed with a mixture of open-ended questions and numeric scales.

The respondents are continuing education students taking the mandatory project management course at NTNU. The genders, educational backgrounds, types of work and experience profiles of the respondents are diverse.

Some students are taking the course as a part of the obligatory requirements to take a competence-based Master's degree in organisation and leadership. Others are taking this course in order to gain a more in-depth understanding of project management methods and practices or because they are looking for new career opportunities in project management.

Around $50 \%$ of the participants are in the age interval between 30-40 years old. They have higher university degrees and some project management experience either as project participants or as project managers.

Table I shows examples from the types of industry and job titles of the selected sample of participants. 
TABLE I. EXAMPLES OF TYPES OF INDUSTRY AND JOB TITLES

\begin{tabular}{|l|l|}
\hline Examples of types of industry & Examples of job title \\
\hline Offshore modifications & R\&D project manager \\
Air traffic control & Senior advisor \\
Consulting & Project manager \\
Higher education, facility & Project leader \\
management & Product marketing learning \\
Civil aviation & manager \\
Automation/Industrial IT & Principal analyst \\
Medical & Support manager / Project \\
Railway & coordinator \\
Construction and maintenance & Maintenance manager \\
Telecommunications & Department manager \\
& Maintenance planner \\
\hline
\end{tabular}

\section{A. Questionnaires}

The questionnaires were sent by e-mail or handed out in person to around 200 students who completed the course in 2009/2010. A total of 83 respondents completed questionnaires but only 54 ultimately returned valid responses for inclusion in the study. Respondents were asked to answer the following questions:

Q1. Define the type of project you are working on currently. Two choices were given to select from: inhouse or a customer project.

The objective of this question was to differentiate between in-house and customer projects. The authors wanted to study to what degree success criteria differ between these two types of projects. Our assumption is that customer projects have more emphasis on success criteria related to the traditional "iron triangle" of cost, time and quality, whereas in-house projects have more emphasis on achieving business objectives and satisfying user's needs.

Q2. The respondents were asked to indicate years of project experience. The objective was to remove responses from respondents with no project experience in order to enhance the validity of the survey.

Q3. The respondents were asked to select the method used to identify success criteria. Two choices were given: agreed upon internally or imposed by the project owner directly or through guidelines describing major business objectives. The goal of the question was to study to what degree the selected criteria are aligned with owners' business goals or strategy. Additionally, we wanted to examine whether the project owner had any guidelines that are used to formulate the criteria.

Q4. This was an open question. The respondents were asked to identify 3-5 success criteria in their current projects. For in-house projects, criteria were then collected and grouped into three categories: 1) criteria that measure cost, time and quality, 2) criteria that measure user satisfaction and achieving functional and operational requirements and 3) criteria that measure achieving strategic or business goals. This classification differs from the existing practice of dividing success criteria in terms of project management success and product/project success [7]. The adopted classification in this paper was based on a time dimension rather than a project versus product one [7]. The first category was measured during project implementation and at close out. The second category was measured within a certain timeframe after project close out or after handing over and close. The last category was also measured after handing over. Percentile statistics will be used to present the results in section III.

\section{B. Evaluation of Research Method}

The research design was developed with three key components in mind; validity, reliability and generalisability [10 p 126]. Generalisability measures the extent to which results can be generalised to other situations. Reliability relates to the extent to which a particular data collection method provides the same results on different occasions. Validity relates to the extent to which the research method measures what it is supposed to measure. In order to enhance validity, only informants that had relevant experience of the problem of the research were selected. The information provided by informants, therefore, is not based on opinion but on actual experience.

Interpreting the findings using the existing literature strengthened reliability. As far as generalisability is concerned, however, we believe that we do have insufficient data to support generalisation; therefore, any generalisation of the findings should be made with caution.

\section{FINDINGS AND ANALYSIS OF THE QUESTIONNAIRES}

Q1 and Q2 addressed the types of project and years of project management experience. The data obtained from the respondents were grouped into two types of respondents:

- Respondents working on in-house projects (Section A below). A total of 25 respondents delivered valid answers. The average working experience of this group was approximately six years.

- Respondents working on customer projects (Section B below). A total of 29 respondents delivered valid responses. The average working experience of this category was 5.8 years.

\section{A. In-House Projects}

Roughly $50 \%$ of the respondents indicated that the criteria are agreed upon internally within the project group as shown in Table II. This might point to a poor alignment between the projects and an owner's business and strategic objectives. This figure might also indicate poor project initiation practice in the owner's organisation.

The data obtained from the respondents' answers to Q4 were grouped into three main categories as shown in Table III. The categories are ranked in terms of the number of times each criterion was identified within each 
category by respondents. This method of ranking does not measure the importance of each category. It measures only the frequency of the criteria in the projects included in the research.

TABLE II. METHODS USED TO IDENTIFY THE CRITERIA

\begin{tabular}{|l|l|l|}
\hline & $\begin{array}{l}\text { Agreed upon internally } \\
\text { within the project group }\end{array}$ & $\begin{array}{l}\text { Issued or decided by } \\
\text { the owner of the } \\
\text { organisation }\end{array}$ \\
\hline Percentage & $48 \%$ & $52 \%$ \\
\hline
\end{tabular}

Table III shows that $77 \%$ of the selected criteria belong to iron triangle-related criteria. This figure reflects a traditional mindset where the focus is on "getting the job done" and seeing success as delivering results on time, within budget and to specifications.

TABLE III. IDENTIFIED CRITERIA AND FREQUENCY

\begin{tabular}{|l|c|c|}
\hline Category & $\begin{array}{c}\text { Number of } \\
\text { times } \\
\text { mentioned }\end{array}$ & $\%$ \\
\hline Iron triangle (cost, time, quality) & 49 & $77 \%$ \\
\hline $\begin{array}{l}\text { User satisfaction (providing value to users, no } \\
\text { complaints, achieving functional and } \\
\text { operational requirements) }\end{array}$ & 11 & $17 \%$ \\
\hline $\begin{array}{l}\text { Achieving business goals (profit, market } \\
\text { position, learning, novelty) }\end{array}$ & 4 & $4 \%$ \\
\hline Total & 64 & $100 \%$ \\
\hline
\end{tabular}

This operational mindset is clearly reflected in the project management literature, which has traditionally used time, budget and quality as the main indicators of project success. Any of these measures-or even all taken together-can lead to an incomplete and misleading assessment, according to Shenhar [1]. Finally, only $4 \%$ of the selected criteria measure the achievement of strategic and business goals such as profit, organisational learning, novelty and market position. This figure stands in contrast to the results obtained by Lipovetsky [11], who studied the relative importance of the dimensions of success and concluded that there is agreement among assessors that the success dimension benefits to the customer is the most important.

These results indicate an alarming signal. Although this survey was collected from respondents working on in-house projects, we observe that achieving strategic and business goals accounted for only $4 \%$ of the answers. This may support our previous observation and suggests a weak or missing link between projects and business and strategic objectives.

In order to examine this conclusion further, we also examined the combinations of these categories as shown in Table IV. Table IV shows that $48 \%$ of respondents reported that all the selected criteria for their projects belong exclusively to the first category (iron triangle or operational success). These do not contain any reference to business goals or corporate strategy. These projects might be classified as projects initiated with no clear rationale al all. Moreover, the results show that only 8\% of the projects have criteria that cover these three categories. This is another indication that the majority of projects in this survey are poorly aligned with corporate strategies and focused only on a narrow operational goals.

TABLE IV. COMBINATIONS OF CATEGORIES

\begin{tabular}{|l|l|l|}
\hline Focus & $\begin{array}{l}\text { Number of } \\
\text { respondents }\end{array}$ & $\%$ \\
\hline Only iron triangle & 12 & $48 \%$ \\
\hline User satisfaction and iron triangle & 7 & $28 \%$ \\
\hline All combinations & 2 & $8 \%$ \\
\hline Other combinations & 4 & $10 \%$ \\
\hline Total & 25 & $100 \%$ \\
\hline
\end{tabular}

B. Customer Projects

Table V shows the results obtained from respondents' answers to Q5.

TABLE V. COMBINATIONS OF CATEGORIES

\begin{tabular}{|l|l|l|}
\hline & $\begin{array}{l}\text { Agreed upon } \\
\text { internally within the } \\
\text { project group }\end{array}$ & $\begin{array}{l}\text { Issued or decided by the } \\
\text { owner of the organisation }\end{array}$ \\
\hline Percentage & $46 \%$ & $54 \%$ \\
\hline
\end{tabular}

The results demonstrate that roughly $50 \%$ of the respondents indicated that the criteria are formulated internally within the project group. This might point to poor project governance practice in the owner organisations in addition to poor alignment with business strategies in the performing organisations. As before, the data obtained from the respondents' answers to Q4 were also grouped into same three main categories as shown in Table VI.

TABLE VI. CRITERIA AND FREQUENCY

\begin{tabular}{|l|l|l|}
\hline Category & $\begin{array}{l}\text { Number of times } \\
\text { mentioned }\end{array}$ & $\%$ \\
\hline Iron triangle & 67 & $74 \%$ \\
\hline User satisfaction & 13 & $14 \%$ \\
\hline Achieving business goals & 11 & $12 \%$ \\
\hline Total & 93 & $100 \%$ \\
\hline
\end{tabular}

The result shows that $74 \%$ of the criteria are related to iron triangle criteria. Here again, we see more emphasis on project management success, which is justified in this case considering that this is a customer project, and completing the project within the constraints of time, cost 
and specifications is at the heart of the performing organisation's responsibilities [12].

We also examined the combinations of these categories as shown in Table VII.

TABLE VII. COMBINATIONS OF CATEGORIES

\begin{tabular}{|l|l|l|}
\hline Focus & $\begin{array}{l}\text { Number of } \\
\text { combinations }\end{array}$ & $\%$ \\
\hline Only iron triangle & 11 & $38 \%$ \\
\hline User satisfaction and iron triangle & 5 & $17 \%$ \\
\hline All combinations & 5 & $17 \%$ \\
\hline Other combinations & 8 & $28 \%$ \\
\hline Total & 29 & $100 \%$ \\
\hline
\end{tabular}

The results show that $38 \%$ of the projects used a combination of iron triangle and client satisfaction criteria. This indicates that projects executed by external contractors have a strong focus on delivering within project constraints as well as achieving customer satisfaction. Another interesting observation is that the majority of these projects (roughly $80 \%$ ) use different combinations of criteria and that they are not entirely focused on iron triangle criteria. This indicates that performing organisations or contractors have a better awareness of projects as agents for creating changes and achieving value. It also indicates better maturity and better project management practices in contractor organisations.

The last question was addressed to both categories of project types. Respondents were asked to indicate if the selected criteria in their last project had to be changed or adjusted during execution. Roughly $84 \%$ of the respondents affirmed that success criteria were changed during execution.

\section{ASSESSMENT OF THE RESUlTS AND CONCLUSIONS}

The obtained results suggest that Norwegian projects are managed using an incomplete set of success criteria. This is evident from the results obtained from respondents working on in-house projects.
There is also a need to formalise the methods used to select these success criteria. There seems to be an urgent need to educate the project management community that there is more to project success than just meeting time, cost and quality constraints. There is also an urgent need to develop better initiation and project governance practices in both owners' and contractors' organisations in order to align projects with business and strategic objectives. The results may also indicate that performing organisations or contractors have a better awareness of projects as agents for creating change and achieving value. It also indicates the better maturity and better project management practices in contractor organisations.

\section{REFERENCES}

[1] A. J. Shenhar, et al., "Project Success: A Multidimensional Strategic Concept," Long Range Planning, vol. 34, 2001, pp. 699725.

[2] G. P. Prabhakar, "What is Project Success: A Literature Review," International Journal of Business and Management, vol. 3, 2008, pp. 3-10.

[3] K. J. R. Müller, "A Retrospective Look at Our Evolving Understanding of Project Success," Project Management Journal, vol. 36(4) , 2005, pp. 19-31.

[4] R. Atkinson, "Project Management: Cost, Time and Quality, Two Best Guesses and a Phenomenon, Its Time to accept Other Success Criteria," International Journal of Project Management, vol. 17, 1999, pp. 337-342.

[5] A. J. Shenhar, et al., "Toward a NASA-Specific Project Management Framework," EMJ - Engineering Management Journal, vol. 17, 2005, pp. 8-16.

[6] A. de Wit, "Measurement of Project Success," International Journal of Project Management, vol. 6, 1988, pp. 164-170.

[7] D. Baccarini, "The Logical Framework Method for Defining Project Success," Project Management Journal, vol. 30, 1999, pp. 25-32.

[8] C. S. Lim and M. Z. Mohamed, "Criteria of Project Success: an Exploratory Re-Examination," International Journal of Project Management, vol. 17, 1999, pp. 243-248.

[9] A. J. Shenhar, et al., "Project Success: a Multidimensional, Strategic Concept," in Innovation in Technology Management. The Key to Global Leadership. PICMET '97, New York, NY, USA, 1997, p. 391, 27-31 July 1997.

[10] D. Crowther and G. Lancaster, Research Methods: a Concise Introduction to Research in Management and Business Consultancy, Amsterdam, Elsevier, 2009.

[11] S. Lipovetsky, et al., "The Relative Importance of Project Success Dimensions," R\&D Management, vol. 27, 1997, pp. 97-106.

[12] J. R. Turner, The Handbook of Project-Based Management: Leading Strategic Change in Organizations, New York, McGrawHill, 2009. 